\title{
DANCING OUTDOORS: \\ DiY Ethics and Democratised Practices of Well-being \\ on the UK Alternative Festival Circuit
}

$\longmapsto$ Feature Article $\longrightarrow$

Alice O'GRADY
University OF LeEDS (UK)

\begin{abstract}
Focussing on the UK's vibrant alternative festival scene, this article examines how traces of the free party movement in the late 1980s continue to pervade the ethos and aesthetic register of contemporary events. It considers the potent DiY ethic of the campsite that emerged as a result of the convergence of Travellers with sounds systems such as Spiral Tribe, Exodus and Bedlam. It examines how the aesthetics and ethics of these rural, grassroots gatherings hark back to a particular moment in British history and how the sights, sounds and cultures of the current festival circuit are intimately connected to the histories from which they grew. The article argues for a reading of outdoor space, as experienced within the frame of the alternative festival, as a locale for the performance of political and personal freedoms. It asks how the cultural legacy of opposition through dancing outdoors serves as an expression of democratic culture and as spatial practice of belonging. The article makes explicit the links between alternative forms of democratic participation and sensations of individual and collective well-being that arise from outdoor dance experiences. Finally, it considers the role of rurality in constructing a festival imaginary that promotes participation, agency and connectivity.
\end{abstract}

KEYWORDS: well-being, democratic culture, rave, alternative festivals, rural space.

Alice O'Grady is Associate Professor in Applied Performance and Head of the School of Performance and Cultural Industries, University of Leeds, UK. Her specialism lies within the field of interactive performance, underground club cultures, festivals and play. She has worked on a number of collaborative, interdisciplinary projects that investigate modes of participation and engagement within a variety of social and playful contexts. She is Section Editor for Dancecult: Journal of Electronic Dance Music Culture.

Dancecult: Journal of Electronic Dance Music Culture 7(1): 76-96

ISSN 1947-5403 @2015 Dancecult http://dj.dancecult.net

http://dx.doi.org/10.12801/1947-5403.2015.07.01.04

ddsncecult 


\section{INTRODUCTION}

Dawn breaks onto a cloudless sky and sunlight sweeps across the fields. Wisps of smoke from last night's fires curl upwards as the ashes float down upon empty beer cans, forgotten items of clothing, and remnants of half eaten meals never to be finished. This is Sunday morning. Two days and two nights of furious dancing in hot dark tents and cold open fields, the sky pierced through with green lasers that go on forever and bounce off blankets of clouds that remind us autumn is on its way. This is Equinox and the tribe have come out to celebrate its passing. The freaks and uniques of Britain have come here to cut loose, to get down and dirty, freewheeling their way into a temporary outdoor world made of mud, hay bales and brightly coloured, handmade decorations that adorn the trees and flap in the breeze creating a salute for dancers who pass by. This is day three of the festival where the excesses of weekend hedonism become etched on people's faces, where walks become staggers as exhaustion takes over and festival refugees litter the campsite like fallen soldiers. When the bags are packed and the debris cleared, and as the raggle-taggle collective prepare for re-entry into the world that lies on the other side of the fence, their faces, though haggard, tell a story of three days well-lived, outdoors with friends, where the elements came to join the party and played alongside them. ${ }^{1}$

The sights, sounds and cultures of the UK's current alternative festival scene have a unique heritage. They spring from a time when music, mobility and dancing outdoors was seen as a potential threat to law and order by the authorities and as a potential point of liberation and emancipation by groups of people committed to self-organization and DiY living. The alternative festival as it is experienced today has its roots in a specific socio-political context. As a cultural phenomenon it belongs to the UK's rich tradition of free festivals and countercultural gatherings, and from there developed as a direct result of the convergence of Travellers with sound systems, i.e. mobile networks of artists, musicians and DJs such as Spiral Tribe, Exodus, Circus Warp, DiY and Bedlam. Scholars of EDM and alternative culture have defined the traveller/raver alliance as one of the most potent subcultural crossovers of recent history, paying particular attention to Glastonbury Festival's pivotal role of importing all night raving into a festival context in the late 1980s and early 1990s (Collin 1997; Rietveld 1998; Worthington 2005; St John 2009). Adopting Glastonbury and other events as critical sites for "facilitating an intimate raver/traveller, crusty/hippy alliance" (St John 2009: 34), sound systems and techno crews rallied at that time under the umbrella of DiY culture (McKay 1998). A cultural hybrid emerged that embodied the libertarian-anarchist principles of Bey's Temporary Autonomous Zone (2003). The actions of those involved and the legislation that came into force thereafter via the Criminal Justice and Public Order Act (1994), changed the way collective dance practices were perceived, not only by the authorities, the media and middle England, but also by those involved in a culture committed to 
using open space opportunistically. Since those days of defiance, rebellion and civil disobedience, gathering outdoors to dance in the fields and woodlands of the British countryside has been reconfigured. Festivals now play a central role in the UK's cultural economy and represent an important growth industry (Jacobs 2011). Despite this process of commercialisation, festivals belonging to the countercultural heritage described above continue to prioritise the rural idyll as an indicator of certain values and ethical choices and use it as a location that offers the possibility of transformation and growth.

Drawing on the notion of the TAZ as a "means of creating an Outside or true space of resistance to the totality" (Bey 2003: xi), this article offers an account of the significance of outdoor space in providing what Bey calls "the 'peak experience' of autonomy" (2003: $\mathrm{x}$ ). It contributes to current discourse on social participation by arguing for a reading of outdoor space, as experienced within the frame of the alternative festival, as a locale for the performance of political and personal freedoms. More specifically, it asks how the cultural legacy of opposition through dancing outdoors serves as an expression of democratic culture and as spatial practice of belonging. Like the "transformational festivals" of the West Coast North American tradition that are explicitly concerned with consciousness awakening, personal growth and spiritual development (Leung 2010), and exemplified by events such as Lightning in a Bottle and British Columbia's Shambhala, rural alternative dance festivals in the UK promote a transformational agenda but in a rather different way and for a different purpose. The broad philosophies of participation, sustainability, responsibility and creative expression are common to both event types and, to some extent languages, imagery and aesthetic sensibilities are shared. However, unlike transformational festivals elsewhere, the $\mathrm{UK}$ variant is underscored by the $\mathrm{DiY}$ spirit of punk. These events possess a harder edge and are linked to a period of civil disobedience that politicised the practice of dancing outdoors. Twenty years on and now part of the regulated leisure industry, the alternative dance festival in the UK is still firmly situated within this countercultural lineage and consciously draws on its aesthetic. At the same time, these events borrow from other traditions (e.g. garden parties, English fetes, camping trips, wilderness adventures) in their evocations of the British countryside. Idyllic pastoral settings are positioned as optimal locations for the events as they offer participants the possibility of reconnecting with more "authentic" ways of living which may lead to some form of personal or social transformation. The alternative rural festival is configured as a space where participation, and the benefits one may draw from it, is prioritised and, to a certain extent, romanticised.

The focus of my discussion is to make explicit the links between alternative forms of democratic participation and well-being, where one arises from and prompts the other to form a virtuous circle. "Well-being" here is understood not only as a subjective state that is characterised by happiness, satisfaction and fulfilment but also as a process, a collective act of what Haworth and Hart call "sense-making" (2007: 1). In this configuration, well-being is not simply about how a person feels on an individual basis but how they make sense of the world through acts of citizenship, engagement and agency. To explore further the 
relationship between collective participation and well-being, the article interrogates the value of dancing outdoors as an articulation of Do It Yourself culture that is perhaps better expressed as "Do It Together". Consciously constructed according to idealistic principles, contemporary alternative festivals provide the opportunity to imagine how life might be lived according to a set of values that differ to those of neo-liberalism. In a world where many cities are in crisis and communities are in free fall, rural festivals act as temporary places of revelry and radical conviviality that offer glimpses of different forms of social organisation. This alternative model is framed and perceived as one that aspires to be more ethical, sustainable, autonomous and inclusive than the day-to-day experience of industrialised, urban living. Focussing on the outdoor and natural context of such events, the article offers a new reading of festival experience as an embodied process that connects people to people and people to place. Braiding the political with the pastoral, the outdoor space of the alternative festival becomes a place where radical togetherness might be enacted, albeit on a temporary stage, and as such offers a critical model for understanding participatory practices across other contexts and locations.

The article utilises data gathered during a period of extended fieldwork that spanned four festival seasons between 2011 and 2014 and covered both the north and south of the UK. Taking an ethnographic approach that included participant observation, interviews and questionnaire surveys, the work focuses on small-scale events, specifically Alchemy, Bearded Theory, Waveform, Solfest, Eden and Nozstock festivals. ${ }^{2}$ Drawing together some of the more distinctive qualities of the British alternative festival, the article considers how this cultural phenomenon has emerged from an outlawed past into a sanctioned present, and analyses the way in which it might offer the potential for a re-enactment of community, using Doreen Massey's concept of space as the context for our collective "becoming" (2005). Taking an eco-psychological perspective, it examines the sensations of interconnectedness that arise from and are associated with collective space-making practices. It contributes to a growing body of research on alternative festivals that seeks to better understand countercultural heritage and its relationship to normative modes of social organisation (McKay 2000; Hetherington 2000; Worthington 2005; Partridge 2006; St John 2014). Building on previous work that examines EDM festivals as alternative playworlds (O'Grady 2015), the article demonstrates how outdoor dance events contribute to what we might call a "festival imaginary" through which participants experience positive sensations expressed variously as spiritual, psychological, physical or social well-being. While one might be sceptical about the ability of the festivals under consideration to develop a new politics of participation to challenge, rival, or even replace neoliberal models, it is nevertheless useful to consider the festival as a form of outdoor discourse that affords participants an immediate sensation of liberation in combination with a critique of the constraints from which they seek escape. How the rural setting plays into this dual process of liberation and critique lies at the heart of this analysis. 


\section{The alternative festival in BRITAin}

Britain's countercultural tradition and the emergence of free festivals are already well documented (Aitken 1990; Hetherington 2000; Worthington 2005; Partridge 2006). Free festivals proliferating in the 1970s were predicated on idealized notions of community, spirituality and authentic connection to the land (Partridge 2006: 41). They promised an alternative, utopian model of living that was based on egalitarian ideals. In the late 1980s, with the explosion of rave culture, these ideals were reconfigured for a new generation and taken up by sound systems such as Spiral Tribe for whom a retreat to the outdoors became part of a strategic exodus out of the city (St John 2009: 41). Partying outdoors became a symbol of freedom and, as Collin suggests, represented a romanticized philosophy where disinherited youth may reconnect with nature (1997: 203). In many ways, this paradigm of rurality as the context for idealized forms of expressive autonomy has altered very little. Today's alternative festivals are predominantly located in rural settings, promise escape from the routines of urbanized daily life, and consciously draw upon a countercultural heritage in which the countryside is both romanticized and politicized in equal measure.

The term "alternative" is, of course, loaded, and highly contestable. It does, however, serve as a useful umbrella term to denote practices that are characterized as oppositional, resistant, marginal and non-conformist. For the purposes of this article, "alternative culture" is used to signify a rejection of what might be perceived as "mainstream". In festival terms, this translates into events modelling themselves differently to the large-scale, highly commercial festivals such as V, Leeds and Reading, Download and Glastonbury (despite the latter's status as being largely responsible for giving birth to alternative festival culture in the UK in the early $1970 s^{3}$ ). Where these events demand huge ticket prices and offer stadium-sized experiences for festivalgoers, alternative festivals ${ }^{4}$ such as Sunrise Celebration, Bearded Theory, Eden, Alchemy and Beautiful Days are small by comparison. Events are framed as grassroots, community-driven occasions that consciously display a commitment to ethical partying, participation, co-creation and collective engagement. Generally, alternative festivals rely heavily on the skills and labour of supporters and contributors who work the festival as volunteers or in exchange for a ticket. Most events provide a holistic experience for attendees by hosting workshops, presentations on arts, crafts and eco-living initiatives, walkabout performances and fire shows, healing areas, massage tents, yoga classes, organic food and market stalls, as well as the requisite programme of live musicians and DJs. Typically, there is an articulation of commitment to sustainability, with green credentials playing a significant part in the promotion of the event. Advertising costs are kept low with events relying predominantly on social media, event loyalty and a single website to facilitate ticket sales. ${ }^{5}$ Overt branding and sponsorship is either rejected entirely or kept to an absolute minimum with traders, stall holders and artists drawn from the local area so that the event benefits the place and people closest to its gates. 


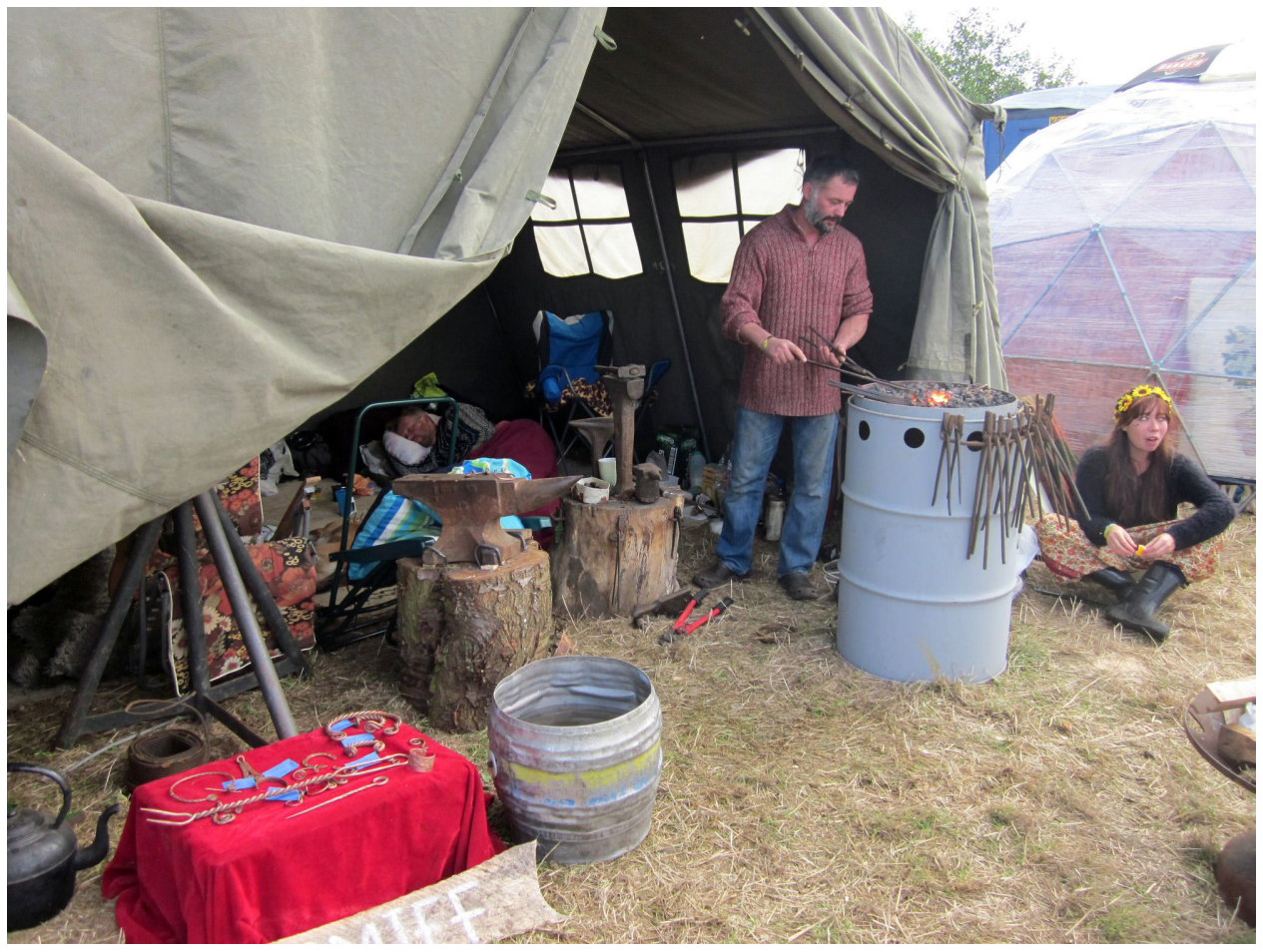

Figure 1. Demonstration of blacksmithing at Alchemy festival. Photo credit: author (2014).

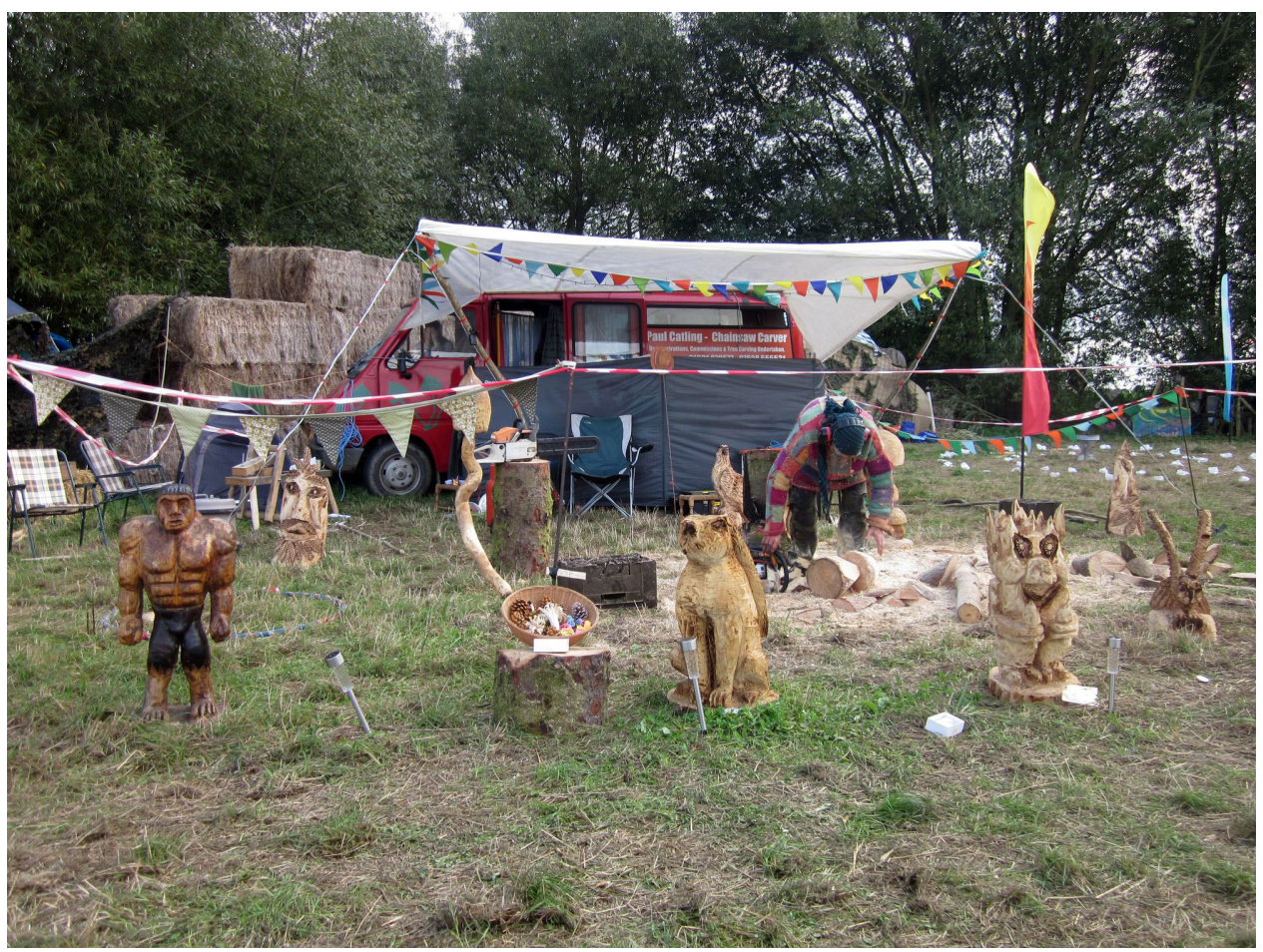

Figure 2. Demonstration of wood carving with Chainsaws at Alchemy festival. PHOTO CREDIT: AUTHOR (2014). 
Although the alternative festival as a paradigm of socially inclusive practice and conscientious living is a common trope that permeates many festival narratives, it is important to remember that they are also messy, unpredictable, chaotic spaces dedicated to hedonism and excess. Fearing crime and public disorder, many living near festival sites object to events taking place on their doorstep. Organizers work hard to maintain good relations with the surrounding neighbours, paying attention to noise pollution and traffic issues in order to keep both licensing officials and local residents happy. Although alternative festivals are part of a wellregulated industry and the threat to rural communities is minimal, they continue to pose a challenge to conservative values not least because they allow people the opportunity to gather en masse, outdoors, in ways they are prevented from doing so elsewhere.

For some, festivals are temporary interruptions to daily life. They provide a brief escape into a hedonistic world that gives respite from workday responsibilities. For others, particularly those who live and work on the circuit, alternative festival culture is both philosophy and lifestyle. The scene contains what George McKay calls "the gamut of alt. culture" and attracts individuals who are drawn to the countryside not only for its natural beauty but also for its potential as "deeply politicised space" (McKay 2000: 121). It is the environmental nature of this politicized space and the freedoms it affords that frames the contemporary experience of festival going. The present cannot be uncoupled from the past. Through intentional restaging of the countercultural aesthetic, today's events provide a platform for the performance, or (re)enactment, of autonomy that not only echoes the past but also meets the current demand for self-actualization through social (and socialized) participation and democratic practice.

\section{OUTDOOR SPACE AND THE PROCESS OF BECOMING}

In the early 1990s, amidst the moral panic surrounding the Travellers and the free party movement, occupation of outdoor space by autonomous groups was seen as a real threat to social order (see Hetherington 2000: 14-17 for full discussion). Performed outdoors and occasionally captured by the press, expressions of collectivity, autonomy and selfdeterminacy were, at this time, destabilizing conventional and restrictive versions of what constituted home, family and kinship. Both the Travellers and the sound systems that had begun to move rave out of urban locations and into the countryside, were beginning to imagine new ways in which people might congregate, live and determine their own leisure practices. These alternative imaginings became concrete through the occupation and utilization of open space. Parties, raves, gatherings and free festivals became the focal point for celebrating alternative living and articulating a multitudinous "quest for freedom" (St John 2009: 32). Collectives such as Spiral Tribe developed a brand of "techno-spirituality" that was rooted in the desire to return to a world where "the disinherited could be connected to natural rhythms and tribal ritual in an open-air dance event" (ibid: 45). With manifestos such as these in place, Britain's countryside became the stage for the performance of autonomy. 
With open space at such a premium, Britons' relationship with the countryside, steeped in sentimentality and nostalgia, has always been highly charged. The control of rural space, who regulates it, protects and manages it, who inhabits, claims and challenges ownership of it remains a persistent concern. Although large, rural free parties that caused moral panic in the early 1990s are a cultural phenomenon of the past, the desire to occupy space autonomously remains. According to Bey, "the Temporary Autonomous Zone appears not just as an historical moment, but also [as] a psychospiritual state or even existential condition" (2003: x). He argues humans are driven by the need to experience autonomy in cohesive groups, as he says "in real space/time" (2003: x). It could be argued that any notion of the TAZ has been effectively deactivated by authorities, who have encouraged its incorporation into the leisure industry as a way of taming it. Alternative festivals look and feel very much like the free parties and gatherings of the past but are strictly controlled and regulated spaces that are required to adhere to stringent health and safety requirements in order to keep their license. However, the TAZ is much more than mere "counter-cultural drop-out-ism" (Bey 2003: 132). Rather, it is a conscious tactic that requires certain conditions rather than particular organisational structures in which to flourish and can, therefore, exist within the frameworks it seeks to oppose.

While the alternative festival may not be a truly autonomous zone as originally conceived by Bey, it continues to provide a "geographical odorous tactile tasty physical space" (Bey 2003: $\mathrm{x}$ ) for the performance of autonomy. It provides a context in which these performances

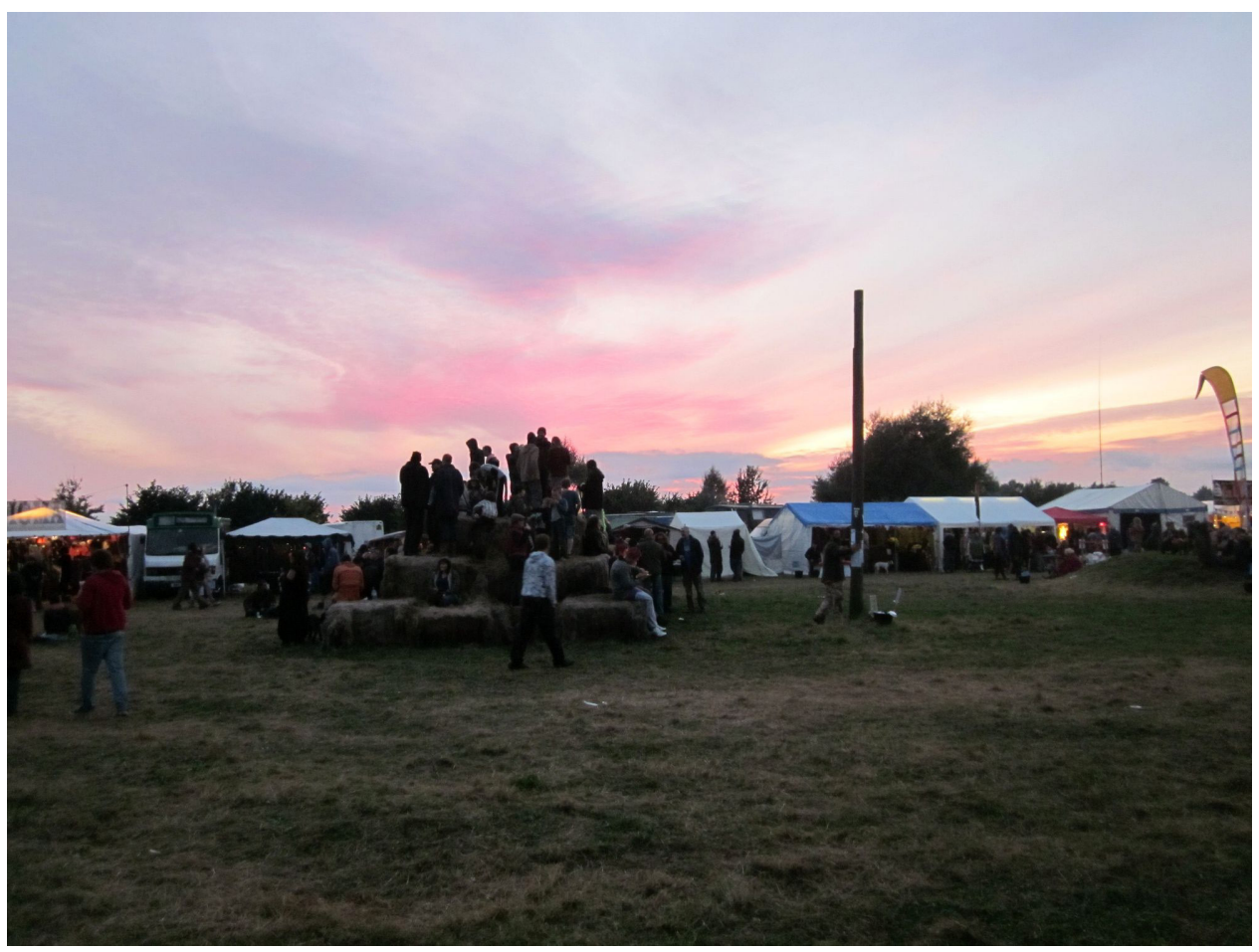

Figure 3. Sunset at Alchemy Festival. Photo credit: author (2012). 
can be enacted alongside and with others. As Massey argues, "we cannot 'become' . . without others. And it is space that provides the necessary condition for that possibility" (2005: 56). Massey calls for space to be recognized as a sphere of possibility that allows for the existence of multiplicity and plurality. As she argues, "space is always in the process of being made. It is never finished; never closed" (2005: 9). In occupying space together and allowing for the interplay of open exchange between people, process is prioritized. The TAZ becomes a space (or perhaps an attitude) in which occupants can work through, or rehearse, what it means to co-exist in a given location. In this analysis, outdoor festival spaces that embrace the elements of chaos, openness and uncertainty in their playful, performative and expressive challenge to mainstream culture are, to adopt Massey's phrase, "creative crucibles for the democratic sphere" (Massey 2005: 153). Festival publicity, in this instance from Nozstock, makes explicit the connections between play and participation and uses it as a framing device and statement of intent:

The festival's ethos is about bringing play to everyone, in whatever form it can. Nozstock believes in the value of not only entertaining, but in participation and contribution. It's an ever-changing event with a clear agenda; to invite conversation, interaction and serious recreation (Nozstock 2015).

The emphasis here is on open interaction through play. There is an invitation extended to participants that positions them as agents in the production of the event (Yeganegy 2012). The implication here is that the very act of participation produces pleasure. In marketing terms, the co-creation model offers insight into changing consumer trends and the "consumption of experience" in, for example, "boutique festivals" (Johannson and Toraldo 2015: 5). However, what participation in the alternative festivals included in my study reveals about identity, identification and psychological gratification is of greater concern. To make the link between democratic practices of participation and psychological well-being, it is necessary to draw upon and braid together a number of concepts, beginning with a geographical analysis of social networks and agency.

\section{DEMOCRATIC CULTURES AND THE POLITICS OF BEING OUTDOORS}

Over the past decade scholars have begun to approach the question of democracy from a geographical perspective (Barnett and Low 2004; Watson 2004). Sophie Watson in her work Cultures of Democracy: Spaces of Democratic Possibility (2004) offers a critique of Robert Putnam's influential book Making Democracy Work (1993) in which he argues political association and democratic engagement are contingent on relatively fixed versions of space such as regions, cities and defined geographical location. Putnam makes the connection between strong networks of civic engagement through clubs, associations, cooperatives and so on, and formal democratic participation. He suggests that horizontal networks such as these are essential forms of social capital. In turn, these networks foster forms of reciprocity and social trust. Reciprocity and trust then translate into functioning democracy within the community (Putnam 1993: 172). Watson, on the other hand, calls for an exploration 
of "democratic cultures" that may occur within "different or less obvious spatial forms" and which may be characterized as "domestic, interstitial, temporary, or fluid" (2004: 207). Using youth rave culture as her example, she argues that "there may, in other words, be a spatial reordering of community and social capital taking place, which at times may not be obvious, which may be shifting or momentary, and which may even be invisible to all but those involved" (Watson 2004: 209). Although not exactly invisible, the shifting, temporary world of the alternative festival is one such place to look for a reordering of community that is predicated on sociability and conviviality. In the festival context, the value of social networks as described by Putnam is undeniable. Indeed, events would not function effectively without them. In line with Watson's modelling however, these networks are fluid, not fixed. They are inherently mobile, more slippery and ultimately contingent. The social sphere of the small-scale alternative festival, allows groups and individuals to build bonds over a short, intense period but without formal commitment. Although subject to immediate evaporation after the event, some of these social bonds are sustained through other mechanisms. A web of interrelations that is developed and maintained, often through social media, reformulates and reconfigures groups across and between festivals. This process involves participants in what Massey might call a dynamic "throwntogetherness" (2005: 181) and invests this version of community with an innate uncertainty but also lends it openness and vitality.

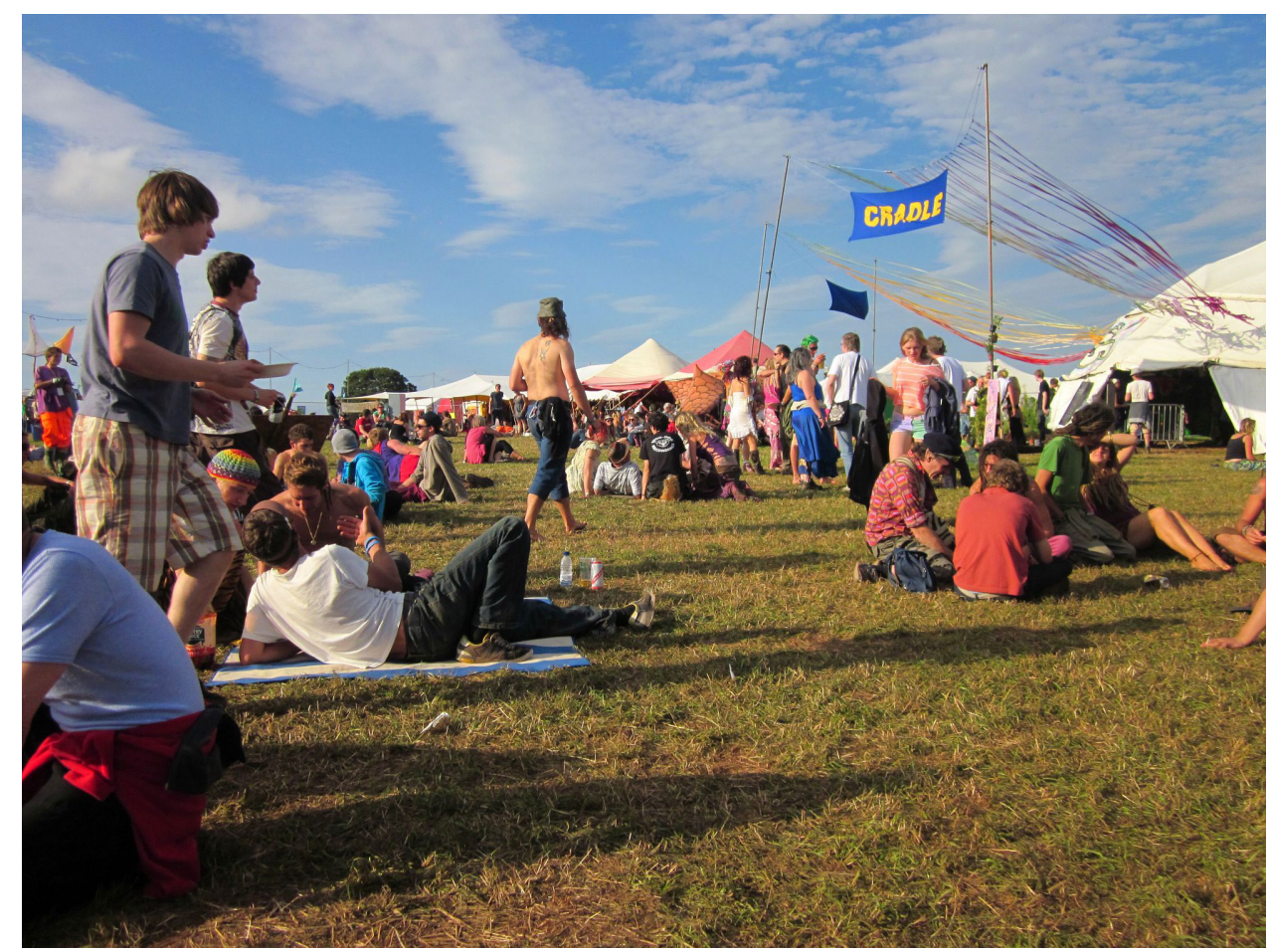

Figure 4: Waveform Festival. Photo credit: author (2012). 
As Massey argues, fixed notions of community can be reconfigured through spatial practice. She suggests, "spatialities of power can be reordered through practices which are more egalitarian, less exploitative and more mutually enabling" (Massey 1999: 284). Experiencing a sense of community, albeit fleetingly so, is perhaps one of the great lures of the alternative festival and, paradoxically, its most potent anti-marketing tool. Putnam argues that since the 1970s people have been systematically pulled apart from each other and their communities (2000). This, he claims, presents a real threat to democracy in action. Although Putnam is offering an analysis of civic participation in the United States, the point is applicable to most Western democracies that rely on citizenship, participation and shared experience to function effectively. Embodied festival practices (camping, eating, drinking, dancing, celebrating outdoors) provide temporary respite from the isolation experienced as a result of the persistent erosion of community. While traditional notions of community may be crumbling, new forms are emerging. Festival communities, although temporary, are opportunities through which some individuals and groups may access the experience of belonging that is denied to them elsewhere. Trust and belonging, unsurprisingly, are key indicators of social well-being. The festival campsite ethic is predicated on cooperation. The tented village is made and unmade over the course of a weekend by those who inhabit it. This self-built space requires certain levels of trust and collaboration to function effectively and, although dissolving at the end of each event, partially meets the needs of participants to experience what it means to live side-by-side with their neighbours in co-created space.

As cultural geographer Jen Jack Gieseking and designer William Mangold suggest, "the process of making and remaking places confirms our agency and responsibility in producing spaces-both material and imagined-that emphasise equality, justice, and democracy" (2014: 393). Adopting the aesthetic register of another era, the alternative festival emphasises the Do it Yourself ethic and spirit of communality. Paradigms of collective action, responsibility and accountability run alongside those of hedonism, self-gratification and consumption. Whatever the paradoxes inherent in this reading, the festive event serves as a leveller. It is open to the elements and all participants are at its mercy. The music is loud; the dancing is tribal. In this setting, non-hierarchical modes of participation are prioritized. There is reverence and respect for festival veterans but celebrity culture is largely rejected. The ethic is one of radical togetherness rather than strategic separation and division. As Watson points out "the free party movement, provided an entirely different cultural space, one which had to be fought for, but one which represented a new form of sociality and which was, arguably, also a democratic space" (2004: 216). Although the cultural space of the free party no longer exists in the same way or with the same potency, it could be argued, that this notion of "democratic space" has been reconfigured into a new cultural product. As Boltanski and Chiapello argue, capitalism absorbs aspects of anti-capitalist critiques into itself (2007). The so called "new spirit of capitalism" is formed out of the critique levelled at its predecessor, in this instance the rave/traveller model of autonomy and authenticity and, in broader terms, the "artistic critique" of 1968 that drove the countercultural movement. In response, the 
new spirit of capitalism appeals to values of self-actualisation, freedom and community. It adopts these principles and markets them. To a certain extent, festival events that situate themselves at the more alternative, radical or transformational end of the spectrum have been subject to this very process of incorporation. However, many festivalgoers are savvy and practised consumers of experience in other parts of their lives. The commodification of "authentic" festival experience does not render the experience meaningless or empty. On the contrary, participants are able to draw pleasure, satisfaction and well-being from events that are consciously created and stage managed as part of a radical socio-political tradition that puts community, autonomy and rurality at its heart.

\section{OUTDOOR SPACE, COLLECTIVE EXPRESSION AND HEDONIC EXPERIENCE}

As music psychologists Jan Packer and Julie Ballantyne point out, although there is a wealth of extant research that looks at the positive health and well-being benefits of engaging with music in a variety of contexts, there is little research conducted on the psychological benefits of music in relation to music festivals (2010: 164). Furthermore, there is even less consideration given to how the outdoor nature of festivals factors into sensations of subjective well-being. Drawing on theoretical frameworks from positive psychology, their study identifies the association of four facets of music festival experience with well-being outcomes. These four facets include the social experience, the festival atmosphere, the music experience, and separation experience. Each facet intersects and supports the other producing a range of social, psychological and subjective well-being outcomes. Although there is some consideration of environment in relation to the separation experience, particularly how the festival provides a different setting to that of daily life or is experienced as a "time out of time" (Falassi 1987), that these events generally take place outdoors and ideally, in the case of alternative festivals, in rural settings of outstanding natural beauty, is overlooked. This omission is surprising given the significance of location to the "anticipated experience" of intensified sensation on offer (Johansson and Toraldo 2015). Appropriating the iconography of the English pastoral, website publicity alludes to "stunning scenery" (Eden Festival 2015), "beautiful grounds" and "woodland areas" (Bearded Theory 2015), "glorious rolling countryside" (Kendal Calling 2015) and "breathtaking beauty" (Green Man 2015). Magikana Festival uses perhaps the most evocative description:

Magikana is located deep in one of the most remote areas of the UK, where the roads end and the wild Cambrian Mountains begin. The area is a protected habitat, and outstandingly beautiful with raw welsh mountain tops and untouched valleys where some of the sources of major rivers of the UK originate. Here you will find Quartz crystal everywhere, endless green hills and craggy cliffs, Red Kites flying, otters in the streams, badgers, foxes, wild ponies and horses, and of course some good ole welsh sheep. On the hills you will also find standing stones, and old stone circles and stunning views as far as the eye can see (Magikana 2013). 


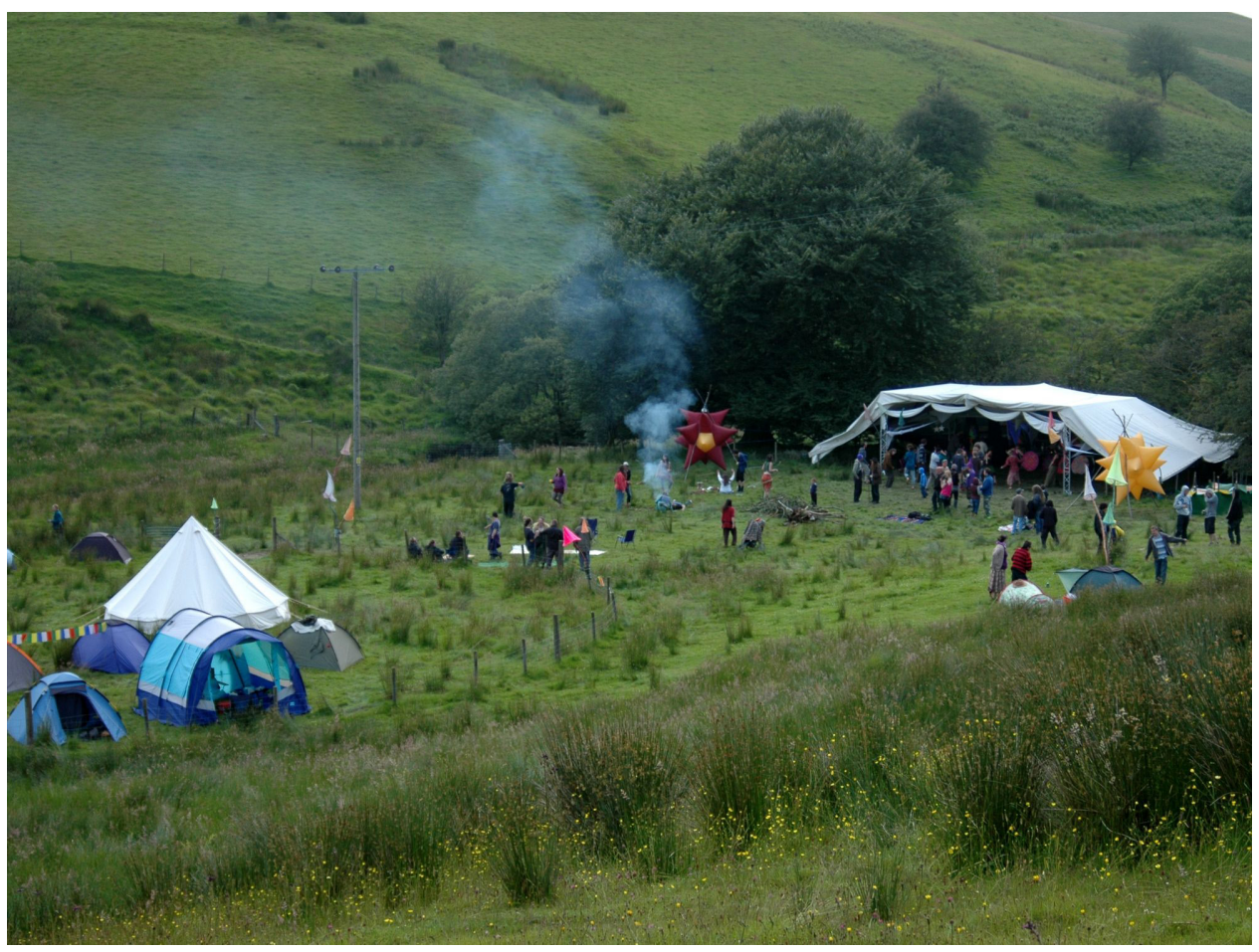

Figure 5: Magikana Festival, Wales. Photo Credit: Allana Angus (2013).

Securing remote rural settings for the purposes of festival represents a geographical marginality that reflects the broader desire to escape into and occupy the idealised liminal world of the forest (O'Grady 2015). Remote locations require commitment and effort not only in terms of travelling to the festival but also necessitate collaboration and cooperation once in situ. Tactical escape into the countryside for the purposes of social gathering, in the UK at least, is steeped in a tangled web of nostalgia, sentiment, history and politics. Participating in contemporary alternative dance festivals forms part of this ongoing narrative and, for some, underpins the meaning they ascribe to it. The idea that being connected to nature has positive outcomes and, in general, makes us feel good may seem intuitive. However, emerging research on the restorative benefits of natural environments from the field of ecopsychology (Rosak 1992; Naess 1995; Herzog et al 2003; Hartig and Staats 2006; Kahn and Hasbach 2012) is providing empirical data that, brought into conversation with that of cultural ethnographers, sheds new light on the potential significance and impact of outdoor dance experiences for effective social functioning and democratization. As Mayer and Frantz argue, increased connection with nature enlarges one's self-concept and builds feelings of "community, kinship, embeddedness, and belongingness" (2004: 512). Furthermore, experiencing positive emotions through connecting with nature can promote both hedonic and eudaimonic aspects of well-being (Wolsko and Lindberg 2013). In other words, the effects are not simply immediately enjoyable and temporary but have lasting and enduring impact in the form of offering a sense of social fulfilment and meaning for those involved. Although festivals are by definition temporary, deriving well-being from the experience may produce effects that extend beyond the time frame of the event and into other realms. 
Clearly self-reported accounts of any potential "impact" on well-being can only provide us with a partial picture of the relationship between embodied experience and psychological benefit. Nonetheless the language participants use in their responses provides some insight into how they perceive the experience for themselves and how it fits within the broader context of self-discovery, community and quasi-spiritual practices of the self as exemplified by transformational festivals with a conscious transitional agenda. When asked whether outdoor festival experiences contribute to their own sense of well-being, all respondents agreed positively. ${ }^{6}$ This was articulated in various ways but included a range of emotional, physical, social and spiritual benefits. The positive benefits were described predominantly as facilitating a process of connectivity, both with other people and the natural environment:

I feel there is a connection between a beat, a movement and the awareness of the landscape... I feel there is a connect with harmony in the landscape...and harmony within the music. $(1)^{7}$

A festival is about being more connected with our true selves, that is with the outdoors, earth and nature. (3)

It deepens my connections with people and place. (19)

Running through the responses was a frequent reference to the interrelation between the music, the people and the earth, and it was this triangulation that seemed to produce the most effusive descriptions of the festival experience as being "meditative", "playful" and "transformative". For respondents, the critical distinction between outdoor and indoor experience was the sensation of freedom. This feeling was expressed as physical, emotional and spiritual release, often in combination. The outdoor environment provided literal space to move and metaphorical space in which to be different. The natural environment was seen to provide the setting for enactments of liberation that were in stark contrast to daily life.

It is a chance to play, to be free, to let go and to flow through troubles and worries in a way that exposes the truth of matters and gives life a focus and a course to follow that wasn't clear without the space, time and clarity of the dance floor. (2)

Having beautiful nature or beautiful art made with love around you creates a space and setting conducive to feeling safe, and free to let go and rise up in your true nature. (2)

Dancing outdoors is bliss, in the sun, in the dark, even in the rain! You can go bonkers as conkers and have the freedom to do so. (13)

The sense of freedom from not being confined produces a spiritual freedom that is reinforced by the direct contact with the natural world, especially for me as a city dweller. For me, it produces a sense of communion. (19) 
In many accounts it was the very act of dancing outdoors, occupying outdoor space freely and expressively, that fostered a sensation of togetherness:

Dancing outdoors can connect me with other people, it is nice to share a beat, share a collective experience. (1)

Dancing outdoors makes me feel alive... Sharing the experience with other people makes me feel more connected to them. (3)

I feel a strong sense of 'secret community'. (4)

The notion of "secret community" here is interesting insofar as it indicates belonging to a group that is somehow protected, clandestine and exclusive. Here the shared moment excludes the outside world as much as it includes those present. The "blissful festival family" (Nozstock 2015) is a powerful trope and reinforces notions of belonging and strengthened familial ties. As well as facilitating connections between people, the festival space was seen to allow connections with place:

[the feeling] is one of connection; connection to the music, to the people, to the earth, to the sky and to myself. To feel united with something greater than I could ever imagine, and yet to get the sense that in this moment, life is so breathtakingly real. (8)

In a busy working life dancing outdoors reminds me of how small I am (we are) and can help me keep things in perspective... It provides me with a chance to reconnect to nature that's different from going for a walk in the hills. The music and nature work in perfect harmony. (18)

This feeling of interconnectedness, or reconnection with something that has been lost, is expressed variously as connection with a more authentic version of self; connection to nature and the universe; reconnection to a simpler way of life; and as connection to one's immediate and present environment. The outdoor locale plays a significant role in facilitating this process of reconnection. The experience is expressed in quasi-spiritual tones with nature configured as being the conduit to authenticity.

Being in the outdoors space can subtly liven our senses and reminds us of our origins. We are the elements; we are nature. By awakening our senses we are creating the conditions whereby we can be open and present and are able to meet and respond in a moment of genuine contact. In the transitional outdoor space we hold the potential to let go of our culturally given roles, associations and resistances and in doing so, we can liberate our energy for full creative expression in relation to the music, to the art, to another and to ourselves. (8)

The outdoor space of the alternative festival is conceived as a space of liberation where "genuine" contact might be made and where individuals take some responsibility for producing those very conditions in which this may occur. There is an implied sense of 
responsibility and accountability woven into this statement that demonstrates a belief in the ability of outdoor space to remind us of the present moment, the here and now. Consistent with Massey's idea that space is constituted through interactions and is the product of interrelations (2005: 5), the outdoor space of the festival is felt, at least, as one that encourages negotiation, encounter and transition.

The English countryside has for centuries provided the context for what we might call the propagation of "the pastoral myth". Life in the country has long been regarded as more wholesome, authentic, natural and spiritually edifying than city living. The idealized countryside acts as a counterpoint to the inequalities and injustices of the city and harks back to a time of communal landownership. As John Short points out, "this image has been the basis of a whole series of rural utopian creeds from Shakers to hippies. It is the communizing of the rural idyll" (1991: 32). In many ways, the environmental ideologies of the alternative festival scene fit neatly into this paradigm. Immersion in a countryside that is of outstanding beauty and remote, is seen as providing the route to the flow experience of festival togetherness (Hetherington 2000: 64):

The experience should be more than 'outdoors', it should be situated in a setting of outstanding natural beauty if possible. (1)

When I think 'outdoors' here I think of a remote site within natural surroundings: be it rural countryside, deep woodlands or remote hills. The further removed from our association with the mundane world, the more potent the effect of the experience. (8)

The experience is seen as providing participants with a potential "effect" that they carry with them back into daily life as they become "reset, recharged, renewed, refreshed, ready for the mundane again" (2). Whether such an effect actually occurs is, of course, subject to speculation. However, what is apparent is the resurgence of the pastoral myth in a time of austerity and widening social inequalities, coupled with a growing and fervent belief that expressions of communality, played out in rural settings are, in some way, good for participants. The aesthetic register and organisational design of events is created to reinforce this pastoral playground, using iconography taken from other contexts such as the village fete, the medieval fayre and the free party/illegal rave in the woods. Alchemy, for example, uses straw bales both as sound proofing devices but also as climbing frames. Straw is scattered around simply for people to play in. Bunting, flags, fairy lights, hand made sculptures and art works are in abundance. A streamside walk under weeping willows leads to healing tents, fire pits and a pedal powered stage. Taking place at the Autumn Equinox, collective celebration of nature is a fundamental part of the event and the free party/Traveller "vibe" evidenced most effectively by the extensive galleries of photographs on the festival's website. ${ }^{8}$

The quest for intimate connection to the natural environment and a deep sense of belonging in space in times of hardship and economic divide, mirror retrospective accounts of rave. As Mark Harrison of Spiral Tribe puts it: 
No matter how remote, how windswept, the show always went on. Every weekend we searched out the few remaining wild places: forests, mountains, moorland...We dodged roadblocks and patrols by navigating back roads, woodland tracks and ancient green lanes. With the ground underfoot as our path and the lie of the land as our guide, we drifted over the edge of the only map we had. Our inner-selves reached out and made new connections with geographical space and geographical space reached in and made new connections with us. We were exploring another England. A synaptic landscape (Harrison, 2013).

Harrison's newly aligned relationship with the landscape might be what Gieseking and Mangold call a type of "spatial imagination" through which we are able to "enact alternative ways of living" (2014: 357). As they argue, by re-making spaces and thereby altering our interactions with others within those spaces, new ways of understanding and representing our place in the world are required. By establishing the presence of a spatial or geographical imagination in which the individual as agent is at liberty to conjure, enact and realize alternatives, we can begin to see how society's relationship with the landscape becomes politically and psychically charged. A reprioritization of the imagination allows the dimensions of the alternative festival to be read as a space of playful potential and social empathy. If festivals provide opportunities for the enactment of imagination, they become potential sites of learning. By dwelling in the imaginative realm for even a short period of time, ways of living differently come into view, empathy can be built and tools gathered to break what is supposedly fixed and finished.

\section{CONCLUSION}

For Gieseking and Mangold, "spatial imagination can open up ways to take notice of being in the world" (2014: 357). The path between the imaginative realm and the concrete world in which we operate is efficacious allowing individuals the freedom to dream how the other might become. The imaginative geographies of festival culture are rooted in historical narratives of political freedoms, opposition and resistance as well as personal narratives of abandon, hedonism and collective play. Imagining alternative places and societies has a long history and the concept of utopia/dystopia in relation to rave culture has been discussed by various commentators seeking to understand and critique the space-making practices of pioneer ravers (Gibson 1999; Reynolds 1998). Of course, these events as cultural products are not without their contradictions. While on the one hand they sit within the tradition of earlier countercultural scenes such as raves, free parties and occupations, from another perspective they are the output of a process of domestication of this same legacy. As ticketed events, it could be argued that what is on offer is a packaged, sanitised, hyperreal version of what was originally conceived as a tangible alternative to mainstream ideologies and capitalist structures. However, if we return to the idea that the TAZ may be understood as an attitudinal stance, a radical tactic emerging within the very structures it seeks to oppose, then it is possible to see that, located in open countryside and with an articulated 
commitment to participation, certain festivals are creating the conditions by which the peak experience of autonomy may be reached. Responses from festivalgoers suggest that their outdoor dance experiences contribute not only to their immediate enjoyment of the event but to their personal sense of well-being, expressed predominantly as interconnectivity and liberation.

If it is possible to accept that alternative festivals that belong to the rave/traveller tradition are providing participants with collective experiences that have the potential to be transformative, then what are the critical factors that contribute to that process? Undoubtedly, the outdoor character of these events means that participation and forms of agency are socialised in more visible and direct ways. Interactions are face-to-face, personto-person, and place-to-person. The removed geophysical character of such events helps individuals and groups congregate, organise and form social bonds in ways that are different to, say, urban events or those that occur indoors. The British countryside is an idealised, romanticised and politicised space. As such, it is the ideal environment for a culture that also oscillates between these positions, often quite intentionally and strategically. The pastoral myth continues to circulate. If nothing else, festival utopias reflect the desire for a more co-located, present way of life that is unmediated. The rural festival offers an escape from the routines of city life and provides participants with a temporary framework for living in a way that makes them feel more connected to both their fellow human beings and the places in which they encounter each other. The wider implication of this is to ask what is occurring in our cities, our homes, our indoor spaces and our virtual worlds that prompts so many people to enact a weekend exodus? What "alternative" are these events offering and how might the model of "three days well-lived" be translated to other contexts where participation, connectivity, critique and agency would be useful, if not urgent, processes to harness?

\section{ACKNOWLEDGEMENTS}

My thanks to everyone who responded to the questionnaire and also to Jeff Gordon of Alchemy Festival for kindly agreeing to be interviewed.

\section{REFERENCES}

Aitken, Don. 1990. "20 Years of Free Festivals in Britain". Festival Eye, 18-21.

Barnett, Clive and Murray Low, eds. 2004. Spaces of Democracy: Geographical Perspectives on Citizenship, Participation and Representation. London: Sage.

Bearded Theory. 2015. < http://www.beardedtheory.co.uk/> (accessed 16 May 2015).

Beautiful Days. 2015. < http://www.beautifuldays.org/about/> (accessed 14 January 2015). 
Bey, Hakim. 2003 [1985]. TAZ: The Temporary Autonomous Zone-Ontological Anarchy, Poetic Terrorism. 2nd revised edition. New York: Autonomedia.

Boltanski, Luc and Eve Chiapello. 2007. The New Spirit of Capitalism. London: Verso.

Collin, Matthew. 1997. Altered State: The Story of Ecstasy Culture and Acid House. London: Serpent's Tail.

Eden Festival. 2015. < http://www.edenfestival.co.uk/\#EDEN> (accessed 16 May 2015).

Falassi, Alessandro. 1987. Time out of Time: Essays on the Festival. Alburquerque NM: University of New Mexico Press.

Gibson, Chris. 1999. "Subversive Sites: Rave Culture, Spatial Politics and the Internet in Sydney, Australia”. Area, 31 (1): 19-33. < http://dx.doi.org/10.1111/j.1475-4762.1999.tb00165.x >

Gieseking, Jen Jack and William Mangold. Cindi Katz, Setha Low, and Susan Saegert. 2014. The People, Place and Space Reader. New York; London; Routledge.

Green Man Festival. 2015. < http://www.greenman.net/> (accessed 16 May 2015).

Harrison, Mark. 2013. Wayward Tales. <http://waywardtales.wordpress.com/> (accessed 3 November 2014).

Hartig, Terry and Henk Staats. 2006. “The Need for Psychological Restoration as a Determinant of Environmental Preferences". Journal of Environmental Psychology, 25: 215-26. $<$ http://dx.doi.org/10.1016/j.jenvp.2006.07.007>.

Hetherington, Kevin. 2000. New Age Travellers: Vanloads of Uproarious Humanity. London; New York: Cassell.

Herzog, Thomas R., Colleen P. Maguire and Mary B Nebel. 2003. "Assessing the Restorative Components of Environments”. Journal of Environmental Psychology, 23: 159-170. <http://dx.doi.org/10.1016/s0272-4944(02)00113-5>.

Howarth, John and Graham Hart. 2007. Well-Being: Individual, Community and Social Perspectives. Basingstoke: Palgrave Macmillan.

Jacobs, Emma. 2011. "Lucrative Celebration: Earning Money from Festivals". Financial Times, 24 March.

Johansson, Marjana and Maria Laura. Toraldo. 2015. “'From Mosh Pit to Posh Pit': Festival Imagery in the Context of the Boutique Festival". Culture and Organization. Published Online. <http://dx.doi.org/10.1080/14759551.2015.1032287>.

Kahn, Peter H. Jr. and Patricia Hasbach. 2012. "Introduction to Ecopsychology: Science, Totems, and the Technological Species". In Ecopsychology: Science, Totems, and the Technological Species, Peter H. Kahn Jr. and Patricia H. Hasbach eds, 1-22. Cambridge MA: MIT Press.

Kendal Calling. 2015. <http://www.kendalcalling.co.uk/> (accessed 16 May 2015).

Leung, Jeet Kei. 2010. “Transformational Festivals”. TEDx Vancouver.

$<$ http://tedxtalks.ted.com/video/TEDxVancouver-Jeet-Kei-Leung-Tr > (accessed 17 May 2015).

Magikana. 2013. < http://www.magikana.org/2013/> (accessed 16 May 2015).

Massey, Doreen. 1999. “Entanglements of Power: Reflections”. In Entanglements of Power, Joanne Sharp, Paul Routledge, Chris Philo, Ronan Paddison eds, 279-286, London: Routledge.

- - - 2000. For Space. London: Sage Publications. 
Mayer, Stephan F. and Cynthia M Frantz. 2004. "The Connectedness to Nature Scale: A Measure of Individuals' Feelings in Community with Nature". Journal of Environmental Psychology, 24: 503-515. < http://dx.doi.org/10.1016/j.jenvp.2004.10.001>.

McKay, George. 1998. DiY Culture: Party and Protest in Nineties Britain. London; New York: Verso.

- - 2000. Glastonbury: A Very English Fair. London: Gollancz.

Naess, Arne. 1995. "Self-realisation: An Ecological Approach to Being in the World". In G Sessions ed., Deep Ecology for the $21^{\text {st }}$ Century, 225-239. Boston, MA: Shambhala.

Nozstock: The Hidden Valley. 2015. <http://www.nozstock.com/>(accessed 16 May 2015).

O’Grady, Alice. 2015. "Alternative Playworlds: Psytrance Festivals, Deep Play and Creative Zones of Transcendence". In The Pop Festival: History, Music, Media, Culture, George McKay ed., 149-164, London: Bloomsbury.

Packer, Jan and Julie Ballantyne. 2011. “The Impact of Music Festival Attendance on Young People's Psychological and Social Well-Being”. Psychology of Music. 39(2): 164-181. <http://dx.doi.org/10.1177/0305735610372611>.

Partridge, Christopher. 2006. “The Spiritual and the Revolutionary: Alternative Spirituality, British Free Festivals, and the Emergence of Rave Culture". Culture and Religion, 7(1): 41-60. < http://dx.doi.org/10.1080/01438300600625408>.

Putnam, Robert. 1993. Making Democracy Work. Princeton, NJ: Princeton University Press.

-_- 2000. Bowling Alone: The Collapse and Revival of American Community. New York: Simon and Schuster.

Reynolds, Simon. 1998. Energy Flash: A Journey Through Rave Music and Dance Culture. London: Picador.

Rietveld, Hillegonda. 1998. This Is Our House: House Music, Cultural Spaces and Technologies. Aldershot: Ashgate.

Roszak, Theodore. 1992. The Voice of the Earth: An Exploration of Ecopsychology. New York, NY: Simon and Schuster.

Short, John Rennie. 1991. Imagined Country. London; New York: Routledge.

St John, Graham. 2009. Technomad: Global Raving Countercultures. London: Equinox.

- - _ 2014. "The Logics of Sacrifice at Visionary Arts Festivals". In The Festivalization of Culture, Andy Bennett, Jodie Taylor, Ian Woodward eds, 49-67. Farnham: Ashgate.

Watson, Sophie. 2004. "Cultures of Democracy: Spaces of Democratic Possibility”. In Spaces of Democracy: Geographical Perspectives on Citizenship, Participation and Representation, Clive Barnett and Murray Low eds, 207-22. London: Sage.

Wolsko, Christopher and Kreg Lindberg. 2013. "Experiencing Connection with Nature: The Matrix of Psychological Well-Being, Mindfulness, and Outdoor Recreation”. Ecopsychology, 5(2): 80-91. <http://dx.doi.org/10.1089/eco.2013.0008>

Worthington, Andy. 2005. Stonehenge: Celebration and Subversion. Loughborough: Heart of Albion Press.

Yeganegy, Roxanne. 2012. “The Politics of Participation: Burning Man and British Festival Culture." PhD Dissertation, University of Leeds. 


\section{NOTES}

1 The opening passage is transcribed from the author's field notes, Alchemy Festival, September 2014.

2 The author's immersive participation in the festivals as a ticket holder was integral to the research methodology and used as an intentional strategy for revealing insight into personal well-being. Each festival was experienced from an "inside" perspective that prioritised first hand experience and intuitive reactions to being outdoors. Reflections on her own embodied responses to events as they unfolded were documented using diaries, notebooks and video in situ at each festival. This documentation was then analysed and considered in light of interview and questionnaire material from festivalgoers that was gathered and returned to the author post event.

3 See George McKay's seminal book Glastonbury: A Very English Fair (2000) for a full discussion of this particular event's history and its relationship to counterculture.

4 Festival nomenclature changes at a rapid rate. Various online festival sites may categorize festivals as "boutique" or "grassroots" but seldom identify an event as "alternative" in the way I am using the term in this article. Many festivals that would see themselves as subscribing to some of the ethical and quasi-political concerns of the free party movement, do not even feature on official listings, preferring to rely on social media networks and word of mouth for advertising and ticket sales.

5 As it states on the Beautiful Days website for example, "Beautiful Days does not advertise and has no corporate sponsorship or branding and has sold out every year in advance" (Beautiful Days 2015).

6 Out of twenty-one respondents only two suggested that dancing outdoors at a festival was no different to dancing indoors.

7 Numbers in brackets are used to identify individual respondents whilst maintaining anonymity.

8 Photographs of Alchemy Festival can be accessed from:

$<$ http://www.alchemyfestival.co.uk/photos.html> 